Communication

\title{
Monitoring of Neotropical Streams Using Macroinvertebrate Communities: Evidence from Honduras
}

\author{
Stefano Fenoglio ${ }^{1,2} \mathbb{D}$ and Alberto Doretto ${ }^{2,3, *}$ \\ 1 Department of Life Sciences and Systems Biology, University of Turin, Via Accademia Albertina, 13, \\ 10123 Turin, Italy; stefano.fenoglio@unito.it \\ 2 ALPSTREAM-Alpine Stream Research Center, 12030 Ostana, Italy \\ 3 Department of Sciences and Technological Innovation, University of Piemonte Orientale Via T. Michel 11, \\ 15121 Alessandria, Italy \\ * Correspondence: alberto.doretto@uniupo.it
}

Citation: Fenoglio, S.; Doretto, A. Monitoring of Neotropical Streams Using Macroinvertebrate Communities: Evidence from Honduras. Environments 2021, 8, 27. https://doi.org/10.3390/

environments 8040027

Academic Editor: Paul C. Sutton

Received: 31 January 2021

Accepted: 30 March 2021

Published: 31 March 2021

Publisher's Note: MDPI stays neutral with regard to jurisdictional claims in published maps and institutional affiliations.

Copyright: (c) 2021 by the authors. Licensee MDPI, Basel, Switzerland. This article is an open access article distributed under the terms and conditions of the Creative Commons Attribution (CC BY) license (https:// creativecommons.org/licenses/by/ $4.0 /)$.

\begin{abstract}
Assessing the water quality by using biological indicators is a reliable and economically feasible way to promote environmental conservation in developing tropical countries. Here, we report one of the few examples of river biomonitoring in Honduras. In June 2005, benthic macroinvertebrates were collected from six sites in the Río Cangrejal basin. An adapted version of the Biological Monitoring Working Party index (BMWP) was used to assess the water quality because it is simple, consolidated, relatively easy to use, and needs a family-level identification. Moreover, two other community metrics were calculated, namely the total taxon richness and local contribution to beta diversity (LCBD). Differences in the biomonitoring and diversity metrics among sites and their correlations were statistically tested. Thirty-nine macroinvertebrate taxa were collected and, despite significant differences in the BMWP score, all sampling sites were classified in the high environmental quality class. A very strong and positive correlation between the BMPW and taxon richness was found, while LCBD did not vary significantly and did not correlate with the other metrics. Our results suggest that taxon richness could be used as a surrogate indicator to assess the water quality when consolidate biomonitoring methods are not available.
\end{abstract}

Keywords: biological indicators; BMWP; richness; LCBD; Río Cangrejal

\section{Introduction}

In the last decades, the biological monitoring of running water systems has become increasingly important and, in many countries, it has become an indispensable complement to traditional chemical-physical techniques in the evaluation of human impacts [1]. Benthic macroinvertebrates are widely used in biomonitoring due to their sensitivity to multiple changes in both the chemical characteristics of the water and the physical properties of the habitats [2-4]. Indeed, benthic macroinvertebrates have overwhelmed other taxonomic groups (e.g., microorganisms, algae and plants, amphibians, and fish) as biological indicators since the publication of the River Continuum Concept [5,6]. The relatively long length of macroinvertebrates' life cycles and their reduced mobility make the analysis of their community structure an effective tool to detect human pressures. Moreover, multiple community metrics might be selected depending on the type of human-mediated alteration, making the river biomonitoring more effective and stressor-specific [7].

The assessment of lotic system health is particularly important in developing tropical countries, where population and economic growth are threatening the exceptional regional biodiversity. Recently, many studies have underlined that biological biomonitoring methods may offer interesting possibilities of application in Neotropical streams [8,9]; may overcome logistic difficulties associated with traditional chemical-physical surveys; and appear advantageous from an economic point of view, providing synthetic information in a rapid way [10]. Besides, the collection and analysis of biological indicators, such as 
benthic macroinvertebrates, requires moderate training, especially when organisms are identified by family. Although knowledge about the benthic macroinvertebrates of the Neotropics [11-16] and their use in biomonitoring $[17,18]$ has increased in the last few decades, it is still scarce, and more extensive investigations are needed.

This study aimed to assess the water quality of Neotropical streams in the Río Cangrejal basin (Honduras), which is under growing pressure from ecotourism and white-water sports. In addition to the application of a monitoring index, the diversity and composition of benthic macroinvertebrate communities was analyzed with the aim of identifying the most biodiverse sites and supporting the best management and conservational strategies in the study area.

\section{Materials and Methods}

\subsection{Area of Study}

The study was conducted in the Río Cangrejal basin, on the northern coast of Honduras. The Río Cangrejal drains a large basin, with a drainage of $498 \mathrm{Km}^{2}$, characterized by the presence of mountains covered by rainforest. The most significant and important mountain of this area is Pico Bonito (2584 m a.s.l.), which has been classified as a national park since 1987. This area features a tropical rainforest climate (Af in the Köppen climate classification) with important rainfall throughout the year (annual mean $=3.5 \mathrm{~m}$ ) and a precipitation peak in winter (October-February) [19]. A total of six sites, localized in the medium-upper part of the hydrographic network, were selected (Figure 1).

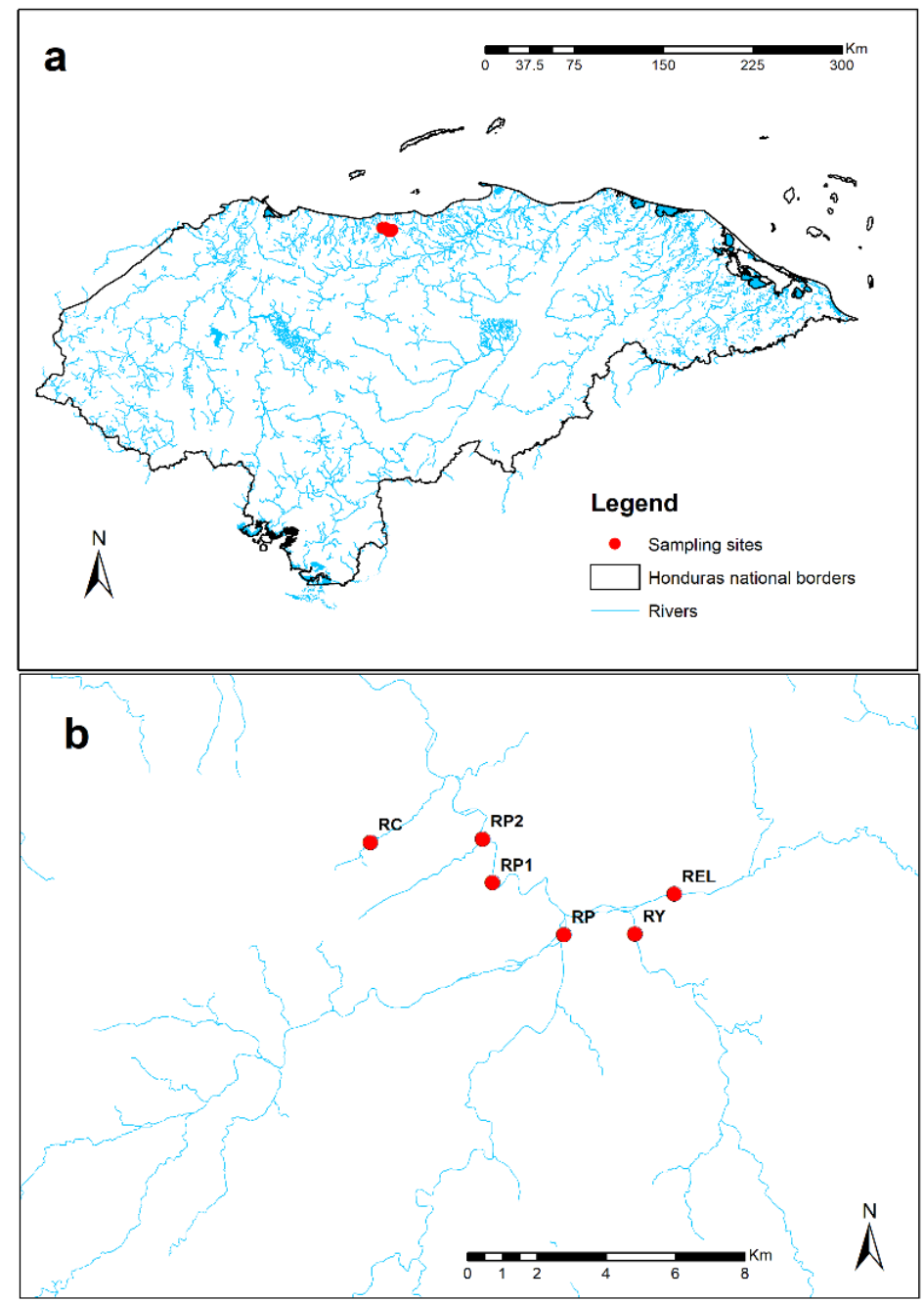

Figure 1. Study area (a) and geographical location of sampling sites (b): REP = Río El Padre, RY = Río Yaruca, RV = Río Viejo, P1 = Río Pital1, P2 = Río Pital2, RC = Río Cangrejal 


\subsection{Data Collection}

In June 2005, benthic macroinvertebrates were sampled from a single riffle area in each site according to the most representative microhabitats and using a dip-in net $(250 \mu \mathrm{m}$ mesh) [20]. The net was placed flush with the river bottom and benthic organisms were dislodged from the substrate immediately upstream from the net by washing the surface of cobbles with the hands or disturbing the substrate with feet. This operation was performed by the same operator, guaranteeing comparability among the samples and sites. Samples were fixed in ethanol $70^{\circ}$ and subsequently sorted and identified in the laboratory with a compound scope $(20 / 60 \mathrm{X})$ to the lowest possible level (genus or family).

\subsection{Data Analysis}

An adapted version of the Biological Monitoring Working Party (BMWP) index (see method details in [21,22]) was used to assess the water quality of the investigated sites, calculated at the family level. Specifically, scores for Neotropical taxa were corrected with those reported in the family-level biotic index [20]. This procedure was adopted because of the need for simple, proven and consolidated methods, applicable immediately and easy to use, with family-level identification. Moreover, this procedure allowed for overcoming the lack of available information on local benthic fauna ecology and was facilitated by the evident taxonomic affinities of local fauna with Palearctic and Nearctic faunas, at least at the family-level. A $\chi^{2}$ test was used to statistically evaluate differences in the BMWP score among sites.

Total taxon richness and the local contribution to beta diversity (LCBD) were calculated for each site. The former corresponds to the total number of taxa, while the latter is a recently proposed measure of ecological uniqueness [23]: sampling sites hosting unique communities (i.e., taxonomically different form the other sites) are scored with high LCBD, thus, contribute to a greater extent to the total regional diversity [23]. Differences in the taxon richness and LCBD among sites were tested by using the $\chi^{2}$ test. Moreover, the Pearson's correlation test was used to quantify the relation between the BMWP and the taxon richness and LCBD.

All analyses were performed with the software R [24], using the basic functions and the adespatial $\mathrm{R}$ package [23] for LCBD and significance of statistical testing was assessed at $p<0.05$.

\section{Results}

A total of 39 taxa belonging to 12 orders were collected (Table 1). Diptera was the taxonomic group with the highest number of taxa, followed by Trichoptera, Ephemeroptera, Hemiptera, and Odonata.

Overall, all sites hosted rich communities of benthic macroinvertebrates with many representatives of the most sensitive taxa, such as EPT (Plecoptera, Ephemeroptera, and Trichoptera). BMWP score varied significantly among sites $\left(\chi^{2}=14.460, p=0.013\right)$ : the lowest score was recorded in Río Viejo, while the highest score was observed in Río El Padre (Figure 2a). However, all sampling sites fall into the "high environmental quality class", because the BMWP score was always higher than 100 (mean $=131.5 \pm 19.5 \mathrm{SD}$ ).

Total taxon richness did not vary significantly among sites $\left(\chi^{2}=5.138, p=0.399\right.$; Figure $2 b$ ). LCBD ranged from 0.147 and 0.222 , but differences among sites were not significant $\left(\chi^{2}=0.023, p=0.998\right.$; Figure $\left.2 c\right)$.

BMWP was positively correlated $(r=0.988, p<0.001)$ with total taxon richness (Figure 2d), but showed no linear association with $\operatorname{LCBD}(r=-0.309, p=0.552$; Figure 2e). Similarly, taxon richness and LCDB were also independent ( $r=-0.384, p=0.452$; Figure 2f). 
Table 1. Presence/absence of the macroinvertebrate taxa in the six sites (REP $=$ Río El Padre, RY = Río Yaruca, RV = Río Viejo, P1 = Río Pital1, P2 = Río Pital2, RC = Río Cangrejal).

\begin{tabular}{|c|c|c|c|c|c|c|}
\hline Taxon & REP & $\mathbf{R Y}$ & $\mathbf{R V}$ & P1 & $\mathbf{P 2}$ & RC \\
\hline \multicolumn{7}{|l|}{ Plecoptera } \\
\hline Anacroneuria & + & & & & & \\
\hline \multicolumn{7}{|l|}{ Ephemeroptera } \\
\hline Baetodes & + & + & + & + & & + \\
\hline Camelobaetidius & + & + & + & + & + & + \\
\hline Leptohyphes & + & + & + & + & + & + \\
\hline Thraulodes & + & + & + & + & + & + \\
\hline Euthyplocia & + & + & & + & & \\
\hline \multicolumn{7}{|l|}{ Trichoptera } \\
\hline Leptonema & & & & + & & + \\
\hline Plectromacronema & & & & + & & \\
\hline Smicridea & & & & & + & \\
\hline Chimarra & + & + & + & + & & + \\
\hline Wormaldia & + & + & & & & \\
\hline Ecnomidae & + & + & + & + & + & + \\
\hline Leptoceridae & & & + & & & \\
\hline \multicolumn{7}{|l|}{ Lepidoptera } \\
\hline Petrophila & + & + & & & & + \\
\hline \multicolumn{7}{|l|}{ Coleoptera } \\
\hline Psephenus & + & & & + & + & + \\
\hline Elmidae & + & + & + & + & + & + \\
\hline Haliplidae & & & & + & & \\
\hline \multicolumn{7}{|l|}{ Hemiptera } \\
\hline Crhyphocricos & + & + & & + & & \\
\hline Limnocoris & + & & & & & \\
\hline Belostoma & + & & & & & \\
\hline Gerridae & + & + & + & + & & + \\
\hline Rhagovelia & + & + & + & + & + & \\
\hline \multicolumn{7}{|l|}{ Diptera } \\
\hline Chironomidae & + & + & + & + & + & + \\
\hline Simuliidae & + & + & + & + & & \\
\hline Sciomyzidae & & & & + & & \\
\hline Limoniidae & + & & + & + & + & + \\
\hline Culicidae & & & & & & + \\
\hline Ceratopogonidae & & & & & & + \\
\hline Tabanidae & + & & & & & \\
\hline \multicolumn{7}{|l|}{ Odonata Anisoptera } \\
\hline Gomphidae & + & & + & + & & + \\
\hline Libellulidae & + & & & & & + \\
\hline Palaemnema & + & & & & & \\
\hline \multicolumn{7}{|l|}{ Odonata Zygoptera } \\
\hline Haeterina & & & & + & + & \\
\hline Argia & + & + & & + & + & + \\
\hline \multicolumn{7}{|l|}{ Megaloptera } \\
\hline Corydalus & + & + & + & + & + & + \\
\hline \multicolumn{7}{|l|}{ Decapoda } \\
\hline Macrobrachium & & & & + & + & + \\
\hline \multicolumn{7}{|l|}{ Tricladida } \\
\hline Planariidae & + & + & + & + & + & + \\
\hline \multicolumn{7}{|l|}{ Gastropoda } \\
\hline Lymnaeidae & & & & + & + & + \\
\hline Ancylidae & + & + & + & & + & + \\
\hline
\end{tabular}


a

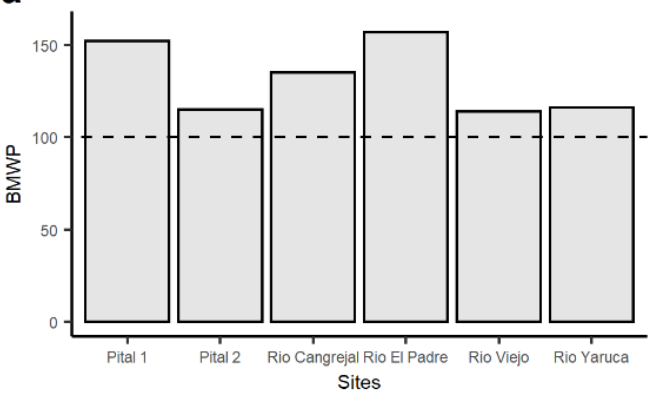

C
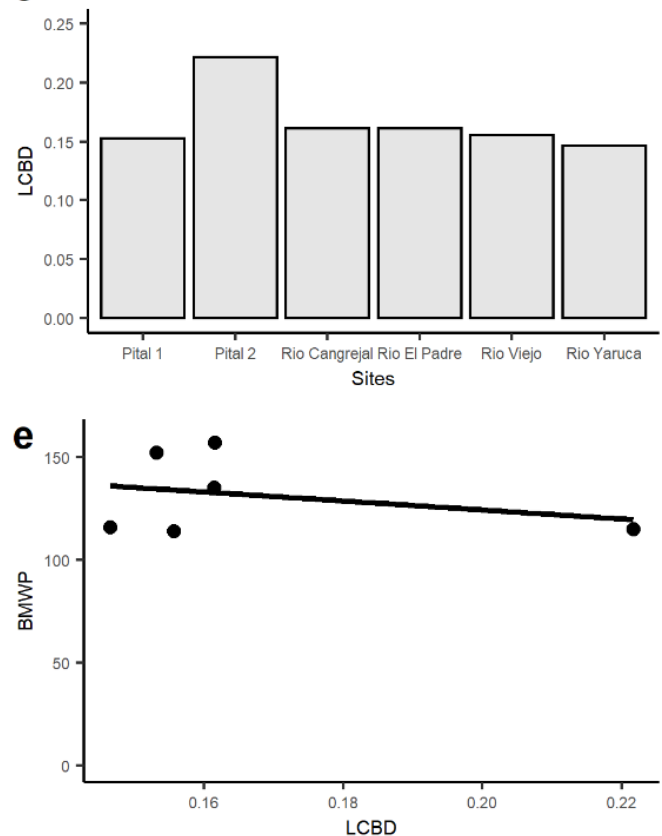

b

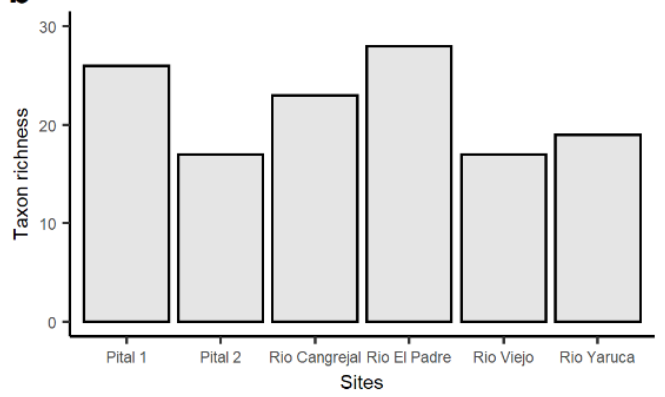

d
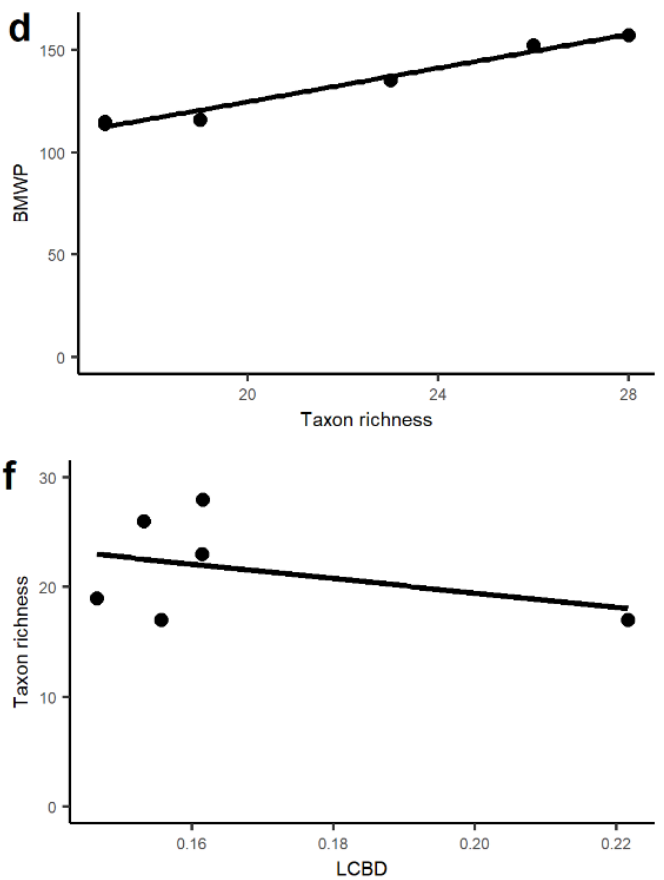

Figure 2. Gray bars represent the following: (a) BMWP score, (b) total taxon richness, and (c) LCBD in all sampling sites. The dashed horizontal line in figure (a) indicates the limit between the class I and class II water quality classes, according to the BMWP methodology [20]. (d) Correlation between the BMWP and taxon richness; (e) correlation between the BMWP and LCBD; (f) correlation between the taxon richness and LCBD.

\section{Discussion}

The development and implementation of effective biological methods for assessing water quality of lotic ecosystems in Honduras, and generally in Central America, is a topic of major importance, considering the growing environmental alteration that affects this region $[25,26]$. However, to our knowledge, only a few studies have been performed to date $[9,27-29]$.

In this context, this study may represent an interesting benchmark. Although there were significant differences in the BMWP score among sites, our results demonstrated in a rapid and relatively economic way that the medium-upper part of the Río Cangrejal hydrographic network was in very good environmental conditions (i.e., class I according to the BMWP methodology). Moreover, we found a strong and positive correlation between this biomonitoring index and the total taxon richness. This finding assumes a great importance and provides useful applications for conservation strategies at local scale because it demonstrates that water quality is closely associated with biodiversity (i.e., taxon richness). In fact, Río Cangrejal is probably the best and most famous place for rafting and white-water sports in Central America. Thus, it is urgent to promote a sustainable use of running waters to accommodate both the demand for recreational tourism and the conservation of biodiversity. Taxon richness is a widely used diversity metric in ecological 
studies on riverine communities $[5,30,31]$ and, when consolidate biomonitoring methods are not available, could be successfully used as a surrogate indicator to assess the water quality $[32,33]$. Our results corroborate this conclusion and indicate that sites with the highest BMWP scores were also the richest ones.

By contrast, LCBD (i.e., a measure of the ecological uniqueness of the sampling sites) offered weak and less informative results in this study. Similar values of LCBD were observed among sites, with the exception of Pital2, and this indicator was scarcely correlated with either BMWP or taxon richness. These findings differed from those obtained in other studies [34,35]. For instance, Ruhí et al. [36] used LCBD to select protected sites in the Albarine River (France). The poor performance of LCBD in this study may be due to our sampling sites being located in a relatively small and near-pristine area, where differences among benthic macroinvertebrate communities were mainly driven by the gain/loss of taxa, rather than species turnover. This conclusion seems supported by our results on the variation in taxon richness among sites, that, albeit not significant, was higher than LCBD.

\section{Conclusions}

In Central American countries, the introduction and diffusion of biomonitoring could bring huge benefits, as it would allow quality control for an entire river network in a reliable and relatively inexpensive way. This study represents a first intent to use benthic macroinvertebrates as biological indicators for lotic ecosystems, in particular using the BMWP index, as well as taxon richness, as reliable and economic biomonitoring methodologies. These results can be the basis on which to implement an effective system of biomonitoring and preservation strategy in relation to various physical and chemical alterations in less-studied geographical areas, such as Honduras. Future goals include increasing the knowledge of the benthic invertebrate fauna taxonomy and ecology, creating taxonomic catalogues, dichotomous keys, reliable application methods, training courses, and reference collections. A major challenge is sensitizing local communities, public opinion, and policymakers about the benefits of better river health monitoring.

Author Contributions: Conceptualization and methodology, S.F.; formal analysis, A.D.; writingoriginal draft preparation, S.F., A.D.; writing-review and editing, S.F., A.D. All authors have read and agreed to the published version of the manuscript.

Funding: This research was supported by USAID-MIRA (Manejo Integrado Recursos Acuáticos) project.

Data Availability Statement: The data presented in this study are available on request from the corresponding author.

Acknowledgments: Authors wish to thank Erika Tenorio, Robert Jordan, José Herrero, and Andrea Orellana from USAID-MIRA Honduras for their friendly support and assistance.

Conflicts of Interest: The authors declare no conflict of interest.

\section{References}

1. Allan, J.D.; Castillo, M.M. Stream Ecology. Structure and Function of Running Waters, 2nd ed.; Springer Editions: Dordrecht, The Netherlands, 2007; pp. 317-358.

2. Buss, D.F.; Carlisle, D.M.; Chon, T.S.; Culp, J.; Harding, J.S.; Keizer-Vlek, H.E.; Robinson, W.A.; Strachan, S.; Thirion, C.; Hughes, R.M. Stream biomonitoring using macroinvertebrates around the globe: A comparison of large-scale programs. Environ. Monit. Assess. 2015, 187, 4132. [CrossRef] [PubMed]

3. Bo, T.; Doretto, A.; Laini, A.; Bona, F.; Fenoglio, S. Biomonitoring with macroinvertebrate communities in Italy: What happened to our past and what is the future? J. Limnol. 2017, 76, 21-28. [CrossRef]

4. Todeschini, S.; Papiri, S.; Sconfietti, R. Impact assessment of urban wet-weather sewer discharges on the Vernavola river (Northern Italy). Civ. Eng. Environ. Syst. 2011, 28, 209-229. [CrossRef]

5. Tornwall, B.; Sokol, E.; Skelton, J.; Brown, B.L. Trends in stream biodiversity research since the river continuum concept. Diversity 2015, 7, 16-35. [CrossRef]

6. Vannote, R.L.; Minshall, G.W.; Cummins, K.W.; Sedell, J.R.; Cushing, C.E. The River Continuum Concept. Can. J. Fish. Aquat. Sci. 1980, 37, 130-137. [CrossRef] 
7. Doretto, A.; Piano, E.; Bona, F.; Fenoglio, S. How to assess the impact of fine sediments on the macroinvertebrate communities of alpine streams? A selection of the best metrics. Ecol. Indic. 2018, 84, 60-69. [CrossRef]

8. Fenoglio, S.; Badino, G.; Bona, F. Benthic macroinvertebrate communities as indicators of river environment quality: An experience in Nicaragua. Rev. Biol. Trop. 2002, 50, 1125-1131.

9. O'Callaghan, P.; Kelly-Quinn, M. Performance of selected macroinvertebrate-based biotic indices for rivers draining the Merendon Mountains region of Honduras. UNED Res. J. 2013, 5, 45-54. [CrossRef]

10. de Jesús-Crespo, R.; Ramírez, A. Effects of urbanization on stream physicochemistry and macroinvertebrate assemblages in a tropical urban watershed in Puerto Rico. J. N. Am. Benthol. Soc. 2011, 30, 739-750. [CrossRef]

11. Ramirez, A.; Pringle, C.M. Structure and production of a benthic insect assemblage in a Neotropical stream. J. N. Am. Benthol. Soc. 1998, 17, 443-463. [CrossRef]

12. Fenoglio, S. Stoneflies (Plecoptera: Perlidae) of Nicaragua. Caribb. J. Sci. 2007, 43, 220-225. [CrossRef]

13. Springer, M. Aquatic insect diversity of Costa Rica: State of knowledge. Rev. Biol. Trop. 2008, 56, $273-295$.

14. Vásquez, D.; Flowers, R.W.; Springer, M. Life history of five small minnow mayflies (Ephemeroptera: Baetidae) in a small tropical stream on the Caribbean slope of Costa Rica. Aquat. Insect. 2009, 31, 319-322. [CrossRef]

15. Fenoglio, S.; Bo, T.; Czekaj, A.; Rościszewska, E. Feeding habits, fine structure and microhabitat preference of Euthyplocia hecuba (Hagen,1861) (Ephemeroptera: Euthyplociidae) nymphs from Honduras. Fol. Biol. 2008, 56, 43-49. [CrossRef] [PubMed]

16. Fenoglio, S.; Bo, T.; Cucco, M. Small-scale macroinvertebrate distribution in a riffle of a Neotropical rainforest stream (Río Bartola, Nicaragua). Caribb. J. Sci. 2004, 40, 253-257.

17. Tomanova, S.; Moya, N.; Oberdorff, T. Using macroinvertebrate biological traits for assessing biotic integrity of Neotropical streams. River Res. Appl. 2008, 24, 1230-1239. [CrossRef]

18. Stein, H.; Springer, M.; Kohlmann, B. Comparison of two sampling methods for biomonitoring using aquatic macroinvertebrates in the Dos Novillos Watershed, Costa Rica. Ecol. Eng. 2008, 34, 267-275. [CrossRef]

19. Smith, J.B.; Strzepek, K.M.; Cardini, J.; Castaneda, M.; Holland, J.; Quiroz, C.; Wigley, T.M.L.; Herrero, J.; Hearne, P.; Furlow, J. Coping with climate variability and climate change in La Ceiba, Honduras. Clim. Chang. 2011, 108, 457-470. [CrossRef]

20. Hilsenhoff, W.L. Rapid field assessment of organic pollution with a family-level biotic index. J. N. Am. Benthol. Soc. 1988, 7,65-68. [CrossRef]

21. Alba-Tercedor, J.; Sanchez-Ortega, A. Un metodo rapido y simple para evaluar la calidad biologica de las agues corrientes basado en el de Hellawell (1987). Limnetica 1988, 4, 51-56.

22. Armitage, P.D.; Moss, D.; Wright, J.F.; Furse, M.T. The performance of a new biological water quality score system based on macroinvertebrates over a wide range of unpolluted running-water sites. Water Res. 1983, 17, 333-347. [CrossRef]

23. Legendre, P.; De Cáceres, M. Beta diversity as the variance of community data: Dissimilarity coefficients and partitioning. Ecol. Lett. 2013, 16, 951-963. [CrossRef]

24. R Development Core Team. R: A Language and Environment for Statistical Computing; R Foundation for Statistical Computing: Vienna, Austria, 2018. Available online: https:/ / www.r-project.org/ (accessed on 19 March 2021).

25. Bradshaw, C.J.A.; Sodhi, N.S.; Brook, B.W. Tropical turmoil: A biodiversity tragedy in progress. Front. Ecol. Environ. 2009, 7, 79-87. [CrossRef]

26. González, E.; Roldán, G. Biological Monitoring of Water Quality in the Americas. In Water Quality in the Americas; Gabriel Roldán, G., Tundisi, J., Jiménez, B., Vammen, K., Vaux, H., González, E., Doria, M., Eds.; IANAS-IAP: Ciudad de México, México, 2019; pp. 37-50.

27. O'Callaghan, P.; Kelly-Quinn, M. Distribution and structure of lotic macroinvertebrate communities and the influence of environmental factors in a tropical cloud forest, Cusuco National Park, Honduras. J. Limnol. 2017, 76, 148-160. [CrossRef]

28. García Lina, A.; Jiménez Otárola, F. Efectos del bosque ribereño y de las actividades antrópicas en las características físico-químicas y en poblaciones de macroinvertebrados acuáticos en la subcuenca del río Tascalapa, Honduras. Rec. Nat. Amb. 2006, 48, 35-46.

29. López, L.I.; Gutiérrez, P.; Mora, J.M. Macrofauna Acuática de la Quebrada Santa Inés, Subcuenca del Río Yeguare, Honduras. Ceiba 2010, 51, 17-28. [CrossRef]

30. Doretto, A.; Bona, F.; Falasco, E.; Morandini, D.; Piano, E.; Fenoglio, S. Stay with the flow: How macroinvertebrate communities recover during the rewetting phase in Alpine streams affected by an exceptional drought. River Res. Appl. 2020, 36, 91-101. [CrossRef]

31. Doretto, A.; Bo, T.; Bona, F.; Fenoglio, S. Efficiency of Surber net under different substrate and flow conditions: Insights for macroinvertebrates sampling and river biomonitoring. Knowl. Manag. Aquat. Ecosyst. 2020, 421, 10. [CrossRef]

32. Sánchez-Montoya, M.M.; Vidal-Abarca, M.R.; Suárez, M.L. Comparing the sensitivity of diverse macroinvertebrate metrics to a multiple stressor gradient in Mediterranean streams and its influence on the assessment of ecological status. Ecol. Indic. 2010, 10, 896-904. [CrossRef]

33. Mebane, C.A. Testing bioassessment metrics: Macroinvertebrate, sculpin, and salmonid responses to stream habitat, sediment, and metals. Environ. Monit. Assess. 2001, 67, 293-322. [CrossRef]

34. Bo, T.; Doretto, A.; Levrino, M.; Fenoglio, S. Contribution of beta diversity in shaping stream macroinvertebrate communities among hydro-ecoregions. Aquat. Ecol. 2020, 54, 957-971. [CrossRef]

35. Tolonen, K.E.; Leinonen, K.; Erkinaro, J.; Heino, J. Ecological uniqueness of macroinvertebrate communities in high-latitude streams is a consequence of deterministic environmental filtering processes. Aquat. Ecol. 2018, 52, 17-33. [CrossRef] 
36. Ruhí, A.; Datry, T.; Sabo, J.L. Interpreting beta-diversity components over time to conserve metacommunities in highly dynamic ecosystems. Conserv. Biol. 2017, 31, 1459-1468. [CrossRef] [PubMed] 